\title{
THE COMPETITIVENESS OF THE LONG-DISTANCE PUBLIC TRANSPORTATION SYSTEM IN SLOVAKIA
}

\author{
Marcel HORŇÁK, Tomáš PŠENKA, František KRIŽAN
}

\begin{abstract}
The long-distance public transport services among the eight regional centres of Slovakia, representing the key urban locations with concentrations of most of the country's services, including business, educational and financial institutions, as well as political power, are examined in this article. It is assumed that the mutual transport interconnections within this group of cities will be a focus for public transport operators in their attempt to gain the largest possible share of potential customers, passengers who would otherwise be users of individual transport means. Hence, one of main aims of this study is to compare public and individual transport modes, and the possibilities offered by them in the mutual interconnections of major regional centres in the country.
\end{abstract}

\section{Shrnutí}

\section{Konkurenceschopnost systému dálkové veřejné dopravy na Slovensku}

Předkládaná studie věnuje pozornost dálkovým spojům veřejné dopravy, které spojují osm regionálních metropoli Slovenska. Ty predstavuji rozhodujicí městská centra a koncentruji ekonomické, vzdělanostní a finanční aktivity i politickou moc $v$ zemi. Práce vycházi $z$ předpokladu, že vzájemné propojení těchto metropoli bude středem pozornosti provozovatelů veřejné dopravy ve snaze získat co největši počet potenciálních zákazníkü - cestujicich, kteří by jinak využili osobní automobil. Proto je jedním z hlavních cílů studie srovnání veřejné a individuální osobní dopravy a možností, které nabizejí ve vzájemném propojení klíčových regionálních center země.

Key words: long-distance transport, public transport, individual transport, regional centres, Slovakia

\section{Introduction}

From the spatial perspective, the public transport system represents an extremely complicated network of links. Although partly subsidized by central, regional or local authorities, the routing and frequency of links and particular services should be optimized to gain a maximum number of passengers and to guarantee the sustainability of public transport as an alternative to individual passenger car transportation. Bussieck (1998), Borndörfer et al. (2007) and others suggest that planning public transport lines should guarantee services, the quality of which is given not only by reasonable cost of travel, safety and convenient means of transport, but also by the quality of lines and schedules.

Mobility trends in Slovakia appear to resemble those in Western Europe where individual transport has a strong position, especially in rural areas with poor public transport networks. In European long-distance transportation, however, the position of public transport is much stronger and still growing (as demonstrated by Paulley et al., 2006), strengthened by intensive political and financial support for high-speed train systems. This is shown explicitly by numerous studies, for example, Couto and Graham (2008) or Lopéz-Pita and Robusté (2005). Deregulation processes in the sector of bus transport services play a role, too. These trends are apparent even in the Slovak Republic, where the process of railway network modernization lags and deregulation has to some degree led to a gradual relative improvement of the services of public transport operators, especially if long-distance and international transport services are considered (see Pšenka, 2011; Michniak, 2007).

With the improvement of Slovakia's road networks and vehicle stock, providers of public transport services will soon have to cope with new challenges. Except for the competitiveness between particular modes of transport, as well as public transport companies, the position of passenger cars is apparently strengthening (see Fig. 1).

Taking into consideration long-distance transportation, the growing network of motorways in Slovakia shortens the travel time between particular regional centres, 


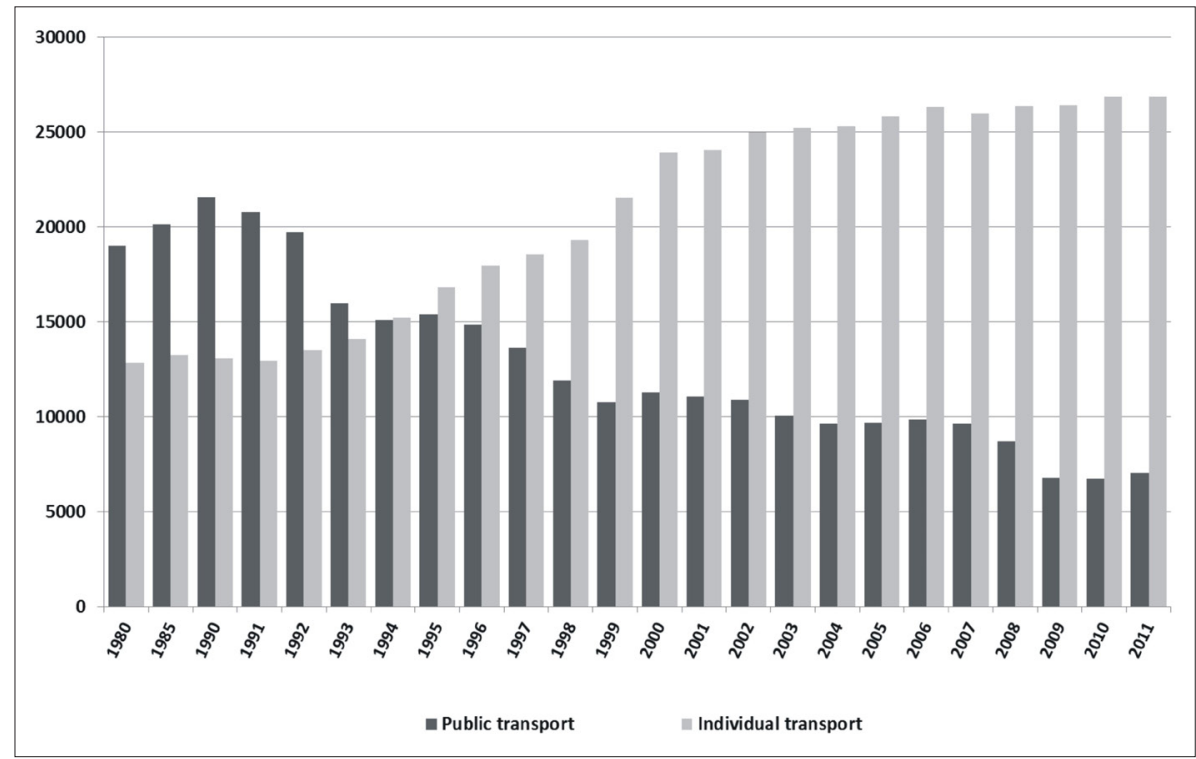

Fig. 1: Public transport and individual transport performance (in million passenger-km) in Slovakia Source: Statistical Office of the Slovak Republic (Slovstat database)

which affords advantages for bus companies and users of passenger vehicles. This is supported by the fact that the modernization of key railway corridors in the country (up to the standard of $160 \mathrm{~km} \cdot \mathrm{h}^{-1}$ ) has been belated so far, and at this moment there is only a short part of the railway network in Slovakia where express trains can travel at standard European speed.

In this research project we analyse the time quality of mutual connections between eight major regional centres of Slovakia in the public transport network (both trains and buses), based on travel times (expressed as a simple measure of accessibility), and on the frequency of connections (for locations of the cities - see Fig. 4). The selected eight regional centres (Bratislava, Trnava, Nitra, Trenčín, Žilina, Banská Bystrica, Prešov and Košice) play a crucial role in the regional and settlement structure of Slovakia as administrative, political, financial and economic cores of eight self-governing regions. From a geographical point of view, however, they do not represent transport cores of the respective self-governing regions and their intra-regional transport accessibility is not always perfect (see Michniak, 2006). As shown by numerous studies by Czech transport geographers, there is a strong relationship between the hierarchy of settlements, position in the administrative system of the country and their transport hierarchy (e. g. Marada et al., 2010; Kraft and Vančura, 2009; Kraft, 2012). Also, some Polish studies underline the importance of location and transport accessibility in the development of large cities (Cudny, 2011; Cudny, 2012; JakóbczykGryszkiewicz, 2011; Stepniak and Rosik, 2013).

Favourable location and the growing road network attract developers and are among important factors of economic development. To evaluate the change in public transport network competitiveness over time, we analyse travel times estimated for travel by passenger cars for the same interconnections. Because the infrastructure of railways and roads, as well as the public transport network serving long-distance travel, are subject to permanent change, our intention is also to show how the parameter of travel times by public and individual transport has changed in Slovakia since the collapse of the socialist regime in 1989.

Theprincipalaim of thispaper thenistoevaluateselected attributes of mutual transport interconnections among eight regional centres in Slovakia (Bratislava, Trnava, Nitra, Trenčín, Žilina, Banská Bystrica, Prešov and Košice), with respect to the spatial (Slovak territory) and temporal (for the years 1989, 1999 and 2011) aspects of transportation. The investigation is focused on a comparative analysis of public (both bus and railway) and individual transportation, with respect to the networks connecting the selected centres.

\section{The changing roles of public and individual transport in Central Europe}

Although 'glorified' for the high shares of public transport compared to passenger cars in the passenger transport modal split at the beginning of the 1990s, Central and Eastern European countries have failed to maintain this "positive" trend due to several factors. These include the growing unemployment rate, changing living standards, and somewhat dubious governmental transport policies (Pucher and Buehler, 2005). New EU member countries (accessed in 2004 and later) have witnessed a considerable decrease in the role of public transport in the 
total performance of passenger transport, which is contrasted to the trends visible in most of the EU-15 member states. From 2000 to 2008, the percentage of passenger cars (of total inland passenger-km) in the EU-27 recorded only a slight change - from $83.1 \%$ to $83.3 \%$. In Slovakia, this proportion grew from $67.9 \%$ to almost $75 \%$; in the Czech Republic from $73.2 \%$ to $76 \%$; in Poland from $72.8 \%$ up to $85.5 \%$; and in Slovenia from nearly $83 \%$ to over $86 \%$ (Europe in Figures, 2011). Due to the turbulent development of transportation systems in the transition societies of Central and Eastern Europe, and the strong impacts that these changes have brought in the modal split of passenger transport, the struggle between individual and public transportation systems in these countries has become a subject of numerous scientific studies.

The volatile modal split and problems stemming from the increasing dominance of individual transport appear to be considered as the crucial issues of passenger transport sector development trends in the transition societies of Central Europe. Dolinayová's (2011) research on the determinants of passengers' decisions on transport mode in the Slovak Republic claims that increasing car-ownership and utilisation of passenger cars result from "new" consumer preferences, but on the other hand they induce road congestions, insufficient parking capacities, air and noise pollution, accidents and fatalities (Pucher and Buehler, 2005). These negative impacts are very much a consequence of underdeveloped road networks in post-socialist countries, as presented by Komornicki (2005) or Horňák (2004).

The economic background of public transport and the system of subsidies for regional transportation became unstable in the 1990s (for details see Van de Velde, 2009), which led to reduced frequency and impaired performance of train and bus services. As far as regional transportation (covering daily commuting) is concerned, the transformation of local labour market structures subverted the regular commuting flows set long before the collapse of the socialist regimes. The growing motorisation of the population and rising prices of regional public transport services led to a decreasing use of regional public transport services, which negatively affected the frequency of the services. This, in turn, leads to a higher dependence on cars, which appears as a serious problem in the less populated areas of Central Europe, where car ownership gradually becomes a necessary condition for life - the so-called "vicious circle" of rural transport, as defined by Nutley, 1998. Similar studies are reported for centralEuropean cases: see Džupinová et al., 2008; Horňák and Džupinová, 2009; Komornicki, 2008; Marada and Květoň, 2010; Marada et al., 2010; and Boruta and Ivan, 2010. Considering the above-mentioned factors,
Ivan (2010a, 2010b) applied commuting distance and commuting price to develop a comparison between individual and public transport modes in some Czech regions, suggesting that carpooling might be a solution for commuting and could compensate for decreasing performances and the rising prices of public transport services. This approach to daily commuting may well apply to long-distance travel, too.

Long-distance public transport, however, might offer more opportunities for public transport providers than regional passenger transport. Comfort, travelling speed and additional services make the long-distance (sometimes called "inter-urban" or "inter-regional" transport) public transport still quite attractive, as claimed by Steg (2003). For this segment, high-speed railways in particular may offer a convincing alternative, as a rival predominantly to air transportation (LopézPita and Robusté, 2005). Nowadays, the post-industrial society induces "more frequent and longer distance inter-urban and regional transport", as stated by Charlton and Vowles (2008). In Slovakia, long-distance trips in the public transport networks are not defined strictly: the law only delimits a minimum of $100 \mathrm{~km}$ from the initial to terminal station for long-distance bus links, to distinguish between subsidized regional transport (up to $100 \mathrm{~km}$ ) and the commercial longdistance public-transport links (Act No. 56/2012 Coll. on Road Transportation). For the purposes of our analyses, all relevant services (see Methods, below) explicitly defined as long-distance services in bus and train travel schedules, were taken into account.

Slovakia belongs to the group of European countries with the lowest share of passenger-car transport, yet it heads towards the EU-27 average values and the trend towards an increasing predominance of passenger cars seems to be irreversible (Fig. 1). Faith (2008) observed that the increasing economic performance of the Slovak economy and thus the rising standard of living of Slovak residents, positively influence the utility rate of passenger cars. This results in the fact that the passenger car gradually becomes dominant in long-distance transfers, as well as in intra-regional and urban transport.

Fig. 1 shows that in terms of transport performance, the passenger car has no more serious rival in the country's passenger-transport market. On the other hand, the public transport system still plays a crucial role in the mobility of people who search (daily or occasionally) for an alternative to a passenger car, or who (for various reasons) cannot afford using a passenger car. However, a matter for discussion might be what is behind the human decision leading to the use of a certain means of transport and what 
factors affect the rate of passenger car use. Numerous scientific studies (including Van Vugt et al., 1995; Marada et al., 2010; Dolinayová, 2011) show that it is almost impossible to predict a human's decision for a certain transport mode. Van Vugt et al. (1995) apply a set of preferences such as social value orientation, day of travel, expectations on others' commuting choices, and congestion to judge an individual's decision. Dolinayová (2011) applies an approach specific for Central European transition societies and differentiates between economic characteristics of residents (unemployment rate, average salary, motorisation rate) and qualitative attributes of transport modes (fees, accessibility of public transport, travelling comfort, timetable co-ordination, etc.). As shown by Limtanakool et al. (2006) who analysed attributes of long-distance travel (trips of $50 \mathrm{~km}$ and over) in the Netherlands, there might be a difference in the weights of individual factors depending on the territorial scale and purpose of travel. According to this study, the passenger car is absolutely dominant in medium- and long-distance business trips, while the propensity of using public transport is higher for leisure trips. In the case of both leisure and business travel, a higher share of travelling by car was detected in households with better passenger car availability. The fact that women tend to use public transport while men travel by passenger car, is not very surprising.

No study has been carried out in Slovakia specifically focused on factors affecting long-distance travellers' preferences. Similarly, there are no statistics revealing the modal split of long-distance trips made in Slovakia. We can only assume that trains are more attractive for longer distances and longer inland trips than buses. Data on passenger-transport volumes and performances in Slovakia (according to the database of the Statistical Office of the Slovak Republic) clearly show two crucial facts related to passenger-transport modal split. First, bus transport has a stronger position in both volume (number of passengers) and performance (number of passenger-kilometres). In 2011 , for example, the share of railways in the total number of passengers reached $2 \%$, while as many as $11 \%$ of passengers travelled by bus. Secondly, the position of railways is relatively stronger in passenger-transport outputs. As of the same year, bus transport still took a larger share (over 13\%) of the total amount of passenger-kilometres, but the share of railways was relatively greater (up to $7 \%$ of the total passenger-transport output in the country) than in the passenger volumes. In other words, passengers make longer trips by trains rather than by buses (on average it was $51 \mathrm{~km}$ by trains, but only $15 \mathrm{~km}$ by buses in 2011). However, no specific data are available on long-distance bus and train links.

\section{Methods}

Assuming that the principal interregional public transport outputs take place among the group of the largest urban cores of a country, in this research we focused on a group of eight cities of the Slovak Republic (in terms of their population size in 2011). These eight cities represent the regional centres of eight self-governing regions (centres of NUTS III) of the Slovak Republic (Bratislava, Košice, Prešov, Žilina, Nitra, Banská Bystrica, Trnava and Trenčín). Institutionally, bus and train public transport services are ordered and subsidized by different public authorities. While the train travel schedules (for both regional and long-distance connections) are created and approved by central institutions under the direction of the Ministry of Transport, Construction and Regional Development of the Slovak Republic, the schedules of public bus networks are supervised by regional self-governments (both regional and long-distance networks). Due to a lack of communication between the central (Ministry) and regional authorities in the process of creating travel schedules, the coordination of bus and train schedules and links is very poor (for details, see Gašparík et al., 2012). Although both bus and train systems of long-distance transport are partly subsidized in order to compensate the public transport providers' economic loss caused by offering reduced fares to students, retired persons, etc. (Kejíková, 2008), they are organized as commercial systems.

The measurement of public transport competitiveness is subject to various discussions. From the geographical point of view, numerous approaches can be used. Partly inspired by Paulley et al. (2006) and Chmelík et al. (2010), we decided to use an available database of public transport services travel timetables to gain data on mutual time accessibility for the selected eight regional centres of the Slovak Republic. In comparison, individual transport travel times were applied to survey the values of accessibility using individual transport by a passenger car. Due to transport infrastructure modernization and extension, the time accessibility values of both public transport and individual transport have changed considerably. Respecting this, we decided to assess indirect effects of investments in transport infrastructure on the mutual competitiveness of buses, trains and passenger cars in terms of time accessibility rates among the selected Slovak cities in three different periods.

As an additional parameter, the frequency of publictransport services among the eight cities was used to measure the quality of bus and train transport. 


\subsection{Database of public transport links}

For our purposes, we analyzed direct train and bus links connecting each of the eight urban centres with the rest of the group. In our opinion, only the direct links can be competitive to individual transport in interregional communication, as one or more changes during a single trip from one region to another may act as a time barrier and bring discomfort for passengers. The survey covers three different periods (1989, 1999 and 2011), which allows us to make judgements on how the time competitiveness of public transport has changed after the collapse of the socialist regime. Printed versions of archived train and bus timetables were used to gain data for the years 1989 and 1999. The 2011 database was accessed via www.busy.sk and www.zssk.sk web pages (in November 2011), internet timetables freely available on the internet. The public transport links and services included in the survey were selected according to the following limitations:

- Train transport: all direct trains including categories of $\mathrm{Zr}$ (fast regional trains), $\mathrm{R}$ (fast trains), Ex (express trains), IC (InterCity trains), EC (EuroCity trains) and EN (EuroNight trains) operated on a routine workday (i.e. at least 5 days per week) were included; and

- Bus transport: all direct international and interregional bus links operated on a routine workday (at least 4 days per week).

In the survey, we searched for the shortest possible train or bus connection for each combination of cities within the group of eight. Travel times necessary to reach either a bus/train station in the town of departure or a target point in the place of arrival, were not considered. The shortest times of interconnections were used for the direct comparison with travel times by individual transport. Where both train and bus links were under operation, the shorter mode was taken into consideration. Intra-regional bus links and regional trains (Os trains) were not considered in our analyses: in terms of travel time, they cannot compete with individual transport. Although the regional train connections can be considered as serving well over short distances (e.g. Košice-Prešov or Trnava-Bratislava), they are hardly competitive at longer distances.

Only direct public transport links were included in our database. According to numerous studies (such as Hine and Scott, 2000; Beirăo and Sarsfield Cabral, 2007, inter alia), interchanges act as serious barriers and they are mostly perceived as negative factors, especially in long-distance travel chains where cumulative delays may occur.

For detailed analysis, two measures of accessibility were applied for each of the regional centres. The first one was a metric accessibility rate, expressed as a cumulative sum of time or distance or cost spent by a traveller to reach each node in the surveyed network. It is defined as a positive measure of accessibility (higher value indicating better accessibility of the node). The metric weight accessibility rate $A c c_{i}$ of the top $i$ in a set $M$ in a graph $G$ is equal to the sum of minimum distances from node $i$ to all other nodes $j$ (each separately) within the set $M$ (Tolmáči, 1999):

$$
\begin{aligned}
& A c c_{i}=\sum_{i=1}^{m} c_{i j} \quad i \in M,|M|=m \\
& a=1,2,3, \ldots, 8 ; i=1,2,3, \ldots, 8
\end{aligned}
$$

The rate was used in three transport networks (car, bus and train). In the study of urban regions (Baxter and Lenzi, 1975), the metric accessibility rate is considered as essential.

A topological weight measure was used as the second accessibility rate. The measure is defined as a total number of lines $L$ (direct connection) between nodes $i$ (origin) and $j$ (destination) due to some variable (time, population, etc.). In our study, a time variable $t$ (number of connections per 24 hours) was used. This measure is directly proportional to the quantity of transportation systems (Tolmáči, 2002):

$$
A c c_{i}=\sum_{i} \frac{L}{t} \quad L=\sum_{i} L_{s 1}+L_{s 2}+\ldots, L_{s n}
$$

where $L_{z x}$ is the number of connections based on station $x$ located in the town and $\mathrm{s}$ is the total number of these stations (in our research, Bratislava was represented by several bus and train stations).

The topological weight measure was used as an additional parameter applied to calculate the rate of public transport competitiveness within the group of eight cities (see below). As claimed by Paulley et al. (2006), the service intervals of public transport may influence the individual's preference. We assume that the more direct public transport connections from one city to another exist per 24 hours, the higher is the probability that a passenger will select one of the public transport means. A passenger car is generally independent and can be used for travelling virtually at any moment, although in some cases this might not be completely true (traffic jams, carpooling).

\subsection{Individual transport database}

To survey the individual transportation attributes, we used the internet version of Google Maps. However, we had to respect Slovakia's status of road infrastructure in the respective years. For the years of 1989 and 1999, new sections of motorways and new road bypasses were excluded to calculate a proper travelling time necessary 
to drive from each of the eight cities to the others. In some cases, archived printed road atlases were used (Atlas ČSSR, 1989; Podrobný autoatlas - Slovenská republika, 1999). The centres of these urban settlements were used as starting and target points, respectively.

\subsection{Synthetic view}

In an attempt to provide a synthetic view, we created a series of simple schematic maps illustrating how the competitiveness of public transport links interconnecting the eight regional centres has changed since 1989. Methodologically, the maps are based on two elementary indicators: travel times by public transport and individual transport, respectively, and frequency of public transport services per 24 hours as an additional indicator reflecting the quality of the public transport network. We applied these parameters to compare the situation in three different years (1989, 1999 and 2011). A combination of the parameters led to the construction of the following categories of public transport competitiveness of particular city-to-city interconnections:

a) competitive public transport connection (travel time longer by a maximum $20.0 \%$ as compared with individual transport travel time for the same cityto-city connection, and 20 or more public transport services/24 hours);

b) partially competitive public transport connection (only one of the above-mentioned conditions for competitiveness is fulfilled); and

c) uncompetitive public transport connection (travel time longer by $20.1 \%$ or more as compared with individual transport travel time for the same connection and 19 or less public transport services/24 hours).

The above-mentioned categories are derived from the simple assumption that commercial speed is a principal factor in a passenger's decision. The factor of service frequency is often used as an indicator of public transport operation, too, and many times as a qualitative counterbalance to the advantages of individual transportation. Although the application of merely two indicators may be seen as a simplification, both parameters are frequently (conjointly or separately) used to measure the quality of public transportation (see e.g. Fellesson and Friman, 2008; Rietveld et al., 2001; Too and Earl, 2010; Beirăo and Sarsfield Cabral, 2007; Paulley et al., 2006; and in the Czech and Slovak literature, see Dolinayová, 2011; Chmelík et al., 2010; Seidenglanz, 2005, etc.).

\section{Results}

Their position within the network of principal railways gives the citizens of the regional centres good opportunities to use train transport, which is (in most cases) faster than bus services. On the other hand, for some interconnections (such as Košice-Banská Bystrica, Bratislava-Nitra, Bratislava-Prešov, NitraTrnava and Košice-Prešov), the poor railway network positions of Nitra, Banská Bystrica and Prešov usually act in a negative way. Table 1 shows that out of 28 possible interconnections within the group, eleven are with no direct train services, usually due again to the location of Nitra, Banská Bystrica and Prešov lacking efficient train coverage with the rest of Slovakia's territory. Bratislava is the only metropolis within the group connected with the other regional centres by both trains and buses; however, direct train connections are not necessarily faster than buses.

The evaluation of public transport accessibility within the group of eight centres of Slovakia shows a slight improvement in the metric accessibility rate for all of the cities after 1989 (see Fig. 2A). Generally, Žilina and Banská Bystrica show the most favourable accessibility, located in central regions of the country. On the other

\begin{tabular}{|c|c|c|c|c|c|c|c|c|c|}
\hline & \multirow[b]{2}{*}{ From/To } & \multicolumn{8}{|c|}{ Public transport modes } \\
\hline & & Bratislava & B. Bystrica & Košice & Nitra & Prešov & Trenčín & Trnava & Žilina \\
\hline \multirow{8}{*}{ 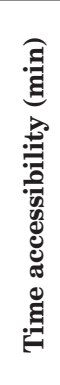 } & Bratislava & $\mathbf{x}$ & & & & & & & \\
\hline & B. Bystrica & 180 & $\mathbf{x}$ & & & & & & \\
\hline & Košice & 282 & 223 & $\mathbf{x}$ & & & & & \\
\hline & Nitra & 63 & 108 & 318 & $\mathbf{x}$ & & & & \\
\hline & Prešov & 432 & 230 & 25 & 350 & $\mathbf{x}$ & & & \\
\hline & Trenčín & 67 & 160 & 220 & 112 & 272 & $\mathbf{x}$ & & \\
\hline & Trnava & 28 & 145 & 263 & 38 & 420 & 40 & $\mathbf{x}$ & \\
\hline & Žilina & 114 & 85 & 164 & 219 & 210 & 54 & 95 & $\mathbf{x}$ \\
\hline & \multicolumn{2}{|c|}{ train faster than bus } & & \multicolumn{2}{|c|}{ bus faster than train } & & \multicolumn{3}{|c|}{ equal travel times } \\
\hline & \multicolumn{2}{|c|}{ bus and train services } & & \multicolumn{2}{|c|}{ bus services only } & & & & \\
\hline
\end{tabular}

Tab. 1: Metric accessibility rates (in minutes) among the regional centres of Slovakia (2011)

Source: Authors' calculations based on bus and train time-schedules (www.cp.sk: accessed in November 2011) 
hand, the peripheral location and lower population of Prešov (as compared with Košice), disadvantage the city in the public transport networks. In the period from 1989-2011, however, the accessibility of Prešov improved most within the group - by more than 70 minutes on average.

The rates for the individual transport metric accessibility (Fig. 2B) are generally better than the public transport means. The effect of the large population size of Košice is balanced by the relatively better location of Prešov within the motorway and highway networks, yet both eastern Slovakia centres show a somewhat peripheral position compared to the others. Considering individual transport accessibility, the concentration of most regional centres in western and central regions of the country shows very clearly in the unfavourable accessibility of Košice and Prešov in the eastern part of the country. Improvement of timeaccessibility by passenger car in 1989-2011 was not as significant as in the case of public transportation; however, Prešov recorded a relatively greater positive change than the rest of the group (improvement by 50 minutes on average).

Public transport links are subject to permanent changes that come annually with the regular publictransport schedule modification. Relevant authorities (such as regional self-governments responsible for bus time-schedules, and the State Railroad Authority for trains) are supposed to grant publictransport links and services that can compete with

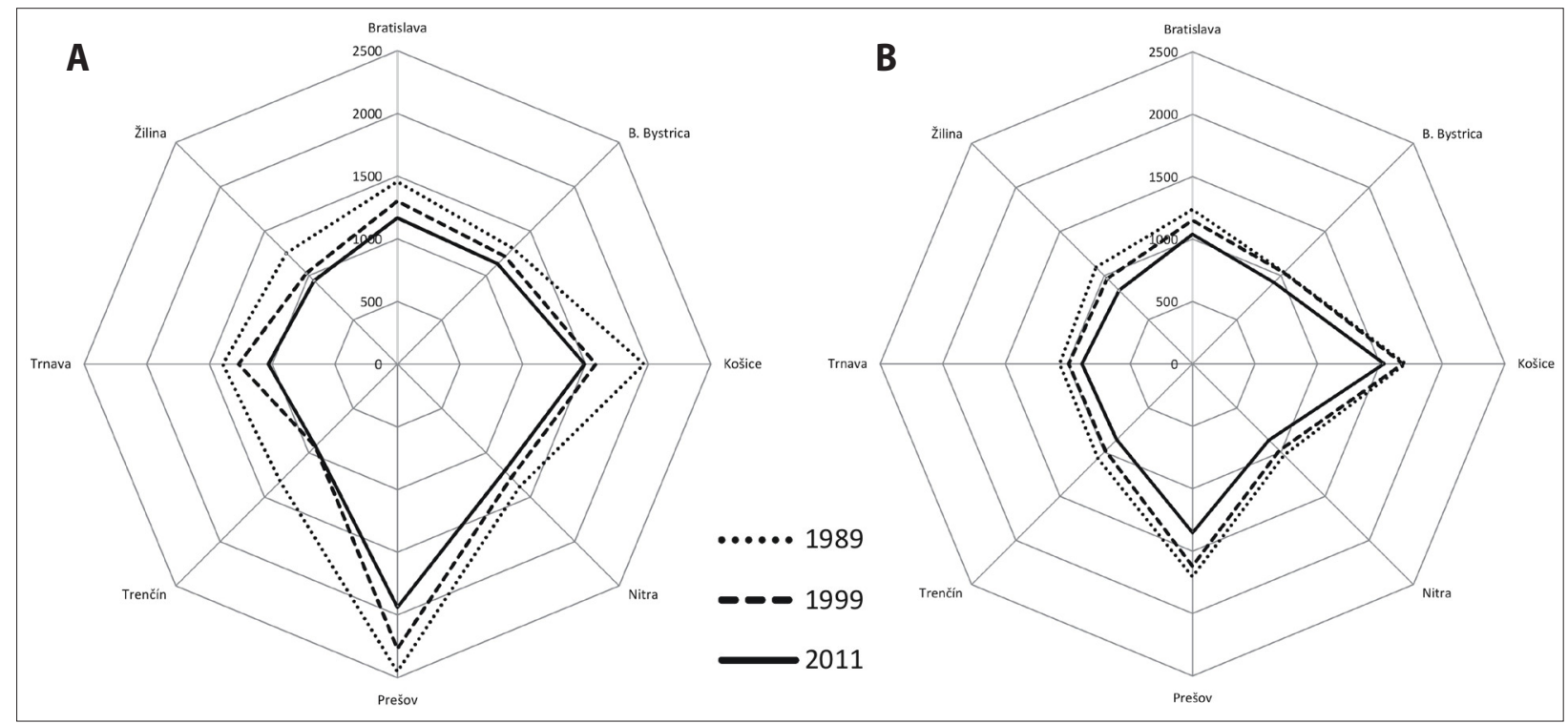

Fig. 2: Metric accessibility (in minutes) of the regional centres in Slovakia by public transport (A) and individual transport (B) in 1989, 1999 and 2011

Sources: Authors' calculations based on bus and train time-schedules (1989, 1999: official printed versions of timeschedules; 2011: www.cp.sk, accessed in November, 2011); Google Maps database (accessed in November 2011); Autoatlas CSSR (1989); Podrobný autoatlas - Slovenská republika (1999).

\begin{tabular}{|c|c|c|c|c|c|c|c|c|c|}
\hline & \multirow[b]{2}{*}{ From/To } & \multicolumn{8}{|c|}{ Public transport } \\
\hline & & Bratislava & B. Bystrica & Košice & Nitra & Prešov & Trenčín & Trnava & Žilina \\
\hline \multirow{8}{*}{ 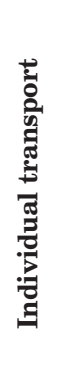 } & Bratislava & $\mathbf{x}$ & 0.78 & 0.79 & 0.74 & 0.85 & 0.72 & 0.82 & 0.78 \\
\hline & B. Bystrica & 0.89 & $\mathbf{x}$ & 1.00 & 0.80 & 0.92 & 1.03 & 0.67 & 0.89 \\
\hline & Košice & 0.93 & 0.95 & $\mathbf{x}$ & 0.81 & 0.74 & 0.63 & 0.65 & 0.82 \\
\hline & Nitra & 0.83 & 0.83 & 0.92 & $\mathbf{x}$ & 0.88 & 1.14 & 0.76 & 1.00 \\
\hline & Prešov & 0.79 & 0.80 & 1.00 & 0.80 & $\mathbf{x}$ & 0.58 & 0.92 & 0.61 \\
\hline & Trenčín & 0.86 & 0.93 & 0.81 & 0.83 & 0.75 & $\mathbf{x}$ & 0.55 & 0.59 \\
\hline & Trnava & 0.99 & 0.87 & 0.93 & 0.97 & 0.78 & 0.83 & $\mathbf{x}$ & 0.61 \\
\hline & Žilina & 0.66 & 1.00 & 0.86 & 0.73 & 0.80 & 0.64 & 0.62 & $\mathbf{x}$ \\
\hline
\end{tabular}

Tab. 2: Change of metric accessibility rates among the regional centres of Slovakia, 1989-2011 (index 2011/1989) Source: Authors' calculations based on bus and train time-schedules (1989, 1999: official print versions of timeschedule; 2011: www.cp.sk, accessed in November 2011); Google Maps database (accessed in November 2011), Autoatlas ČSSR (1989), Podrobný autoatlas - Slovenská republika (1999). 
individual transport. However, they can hardly affect the shape and condition of the current transport infrastructure that allows trains and buses to reach travel times comparable with travelling by passenger car. Nevertheless, both railway and road networks of Slovakia have experienced considerable changes in terms of quality and length throughout the recent two decades, which could have brought positive effects on travel times (Table 2).

Individual transport travel times have either remained stable or improved due to continual enhancement of highway and motorway networks. In some connections (such as Bratislava-Žilina or Banská BystricaTrnava) we can see a considerable effect of motorway construction realized by 2011. In other directions (Banská Bystrica-Trenčín or Banská Bystrica-Košice), only slight improvements of highways (e.g. building of bypass roads for transit traffic) may have changed travel times for individual transport.

In some connections (Trnava-Trenčín, ŽilinaTrenčín), one can see an extremely positive change of public-transport travel times, too. This may result from both infrastructure enhancements as well as from the modifications of time-schedules of public transport services. In some cases, the time has been cut down due to the introduction of the IC/ EC category of trains with only a few stops from the starting point to the destination, which may improve travel times significantly (e.g. by $45 \%$ in the TrnavaTrenčín connection). On the other hand, connections where bus links represent the only direct public transport (e.g. Trenčín-Nitra or Trenčín-Banská Bystrica), have recorded slightly increased travel times as a result of bus-schedule modification aimed at using the potential of passengers from smaller towns situated between the bus service starting point and destination.

The topological weight accessibility (detected via daily public transport interconnections, see Fig. 3) differs markedly between the capital city of Bratislava and the other cities. In spite of the extremely peripheral position of Bratislava, the city still dominates the public transport networks due to its central role in the political and economic system of the country, while the low number of daily direct links to other regional centres documents the peripheral position of Prešov within the public transport networks. Generally, the frequency of daily links has grown since 1989 within the group of centres; nevertheless, the highest frequency growth has been recorded in the eastern regional centres of Košice and Prešov (by $51 \%$ and $130 \%$, respectively).

Surprisingly, the series of schematic maps in Fig. 4 suggests that the quality of public services (with respect to simplifications in the methods applied) connecting the main regional centres in Slovakia has been increasing. As to the capital city, four public transport links (out of seven in total) connecting Bratislava with the other regional centres were fully competitive in 1989 , with six and five public transport links being fully competitive in 1999 and 2011, respectively.

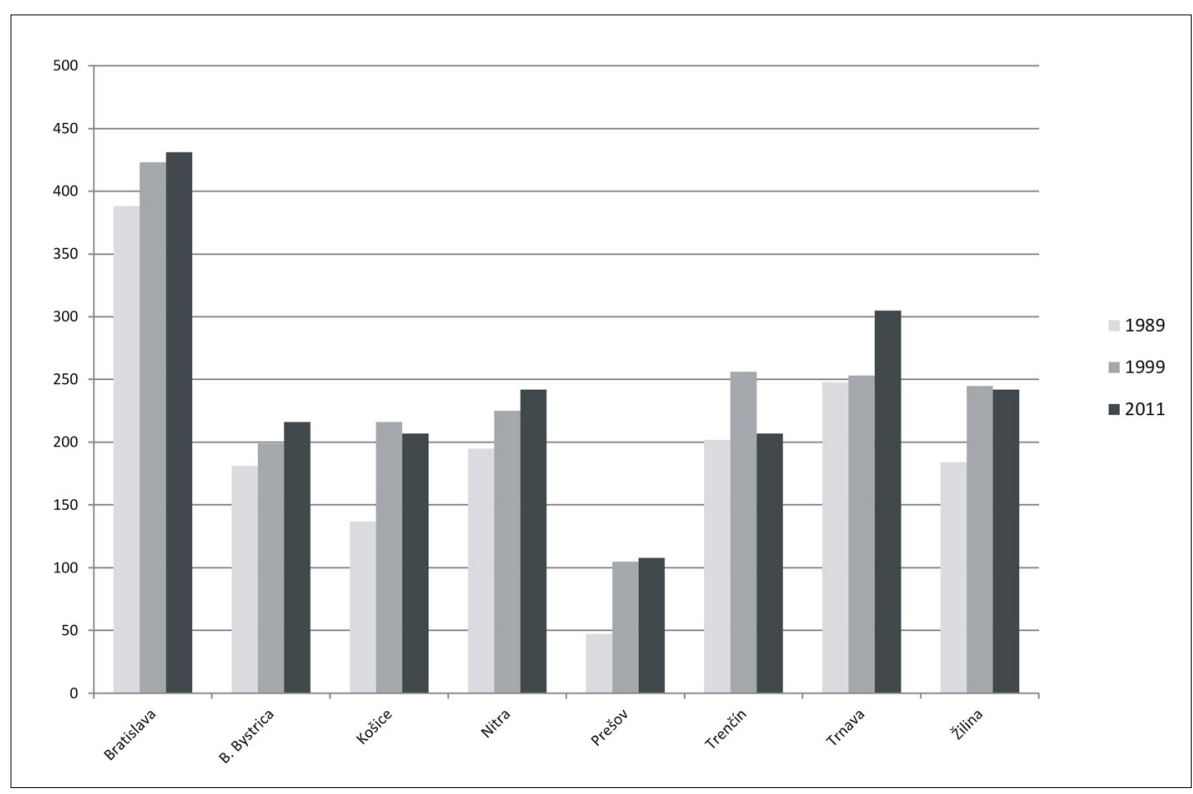

Fig. 3: The topological weight accessibility (public transport, per 24 hours) among the eight regional centres of Slovakia $(1989,1999,2011)$

Source: Authors' calculations based on bus and train time-schedules (1989, 1999: official print versions of timeschedule; 2011: www.cp.sk accessed in November 2011) 
The second regional centre of Košice improved its interconnections from two fully competitive links in 1989 up to five in 1999 and 2011. Trnava improved its position, too, with only three fully competitive links in 1989, but six in 2011. One can see an evident improvement of Nitra's position within the network, with no fully competitive link in 1989 and three fully competitive links in 1999 and 2011. The position of four cities has changed slightly. Banská Bystrica had two fully competitive public transport links and three partially competitive links in 1989 . The shift to three fully competitive connections and two partially competitive links in 2011 indicates only a partial change. Similarly, Prešov showed a slight change, gaining only one fully competitive link in 1989-2011. On the other hand, Trenčín recorded a moderate impairment of its interconnections, keeping four fully competitive links throughout the whole period, but losing two partially competitive links. Žilina's

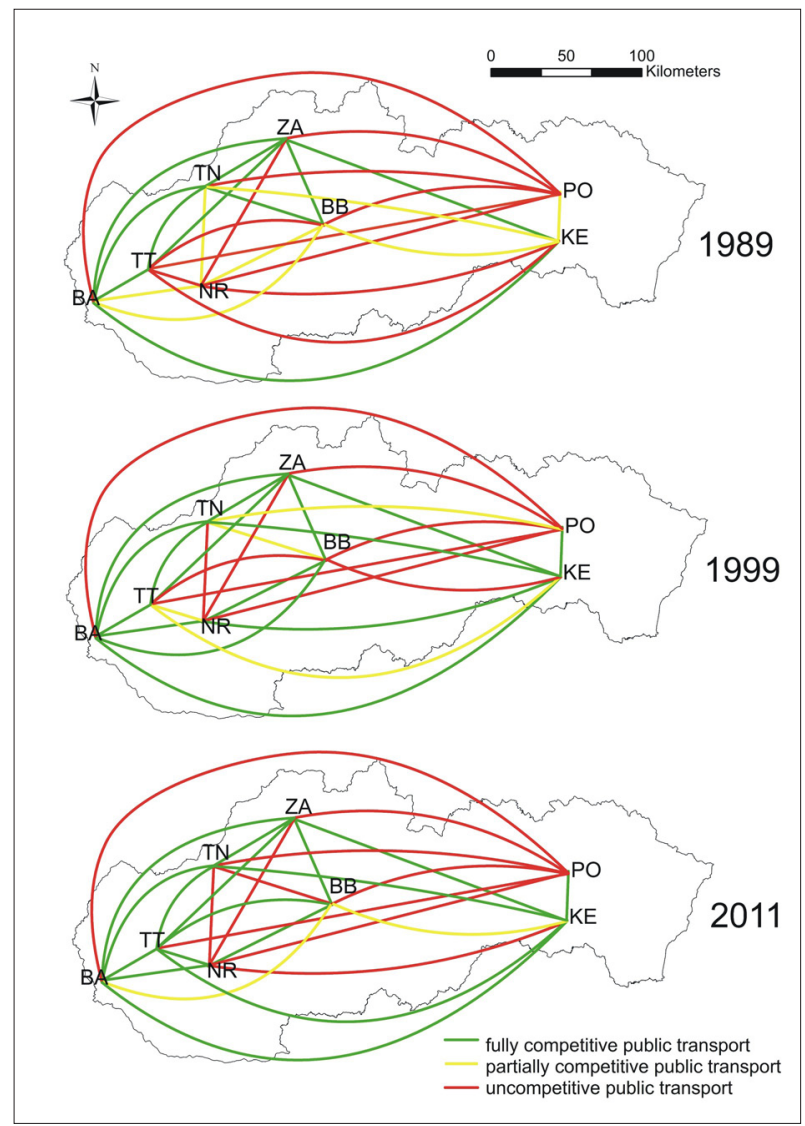

Fig. 4: Competitiveness of city-to-city public transport links among the regional centres of Slovakia $(B A=$ Bratislava,$\quad T T=$ Trnava,$\quad T N=$ Trenčin, $N R=$ Nitra,$\quad Z A=$ Žilina,$\quad B B=$ Banská Bystrica, $P O=$ Prešov, $K E=$ Košice)

Source: Authors' calculations based on bus and train time-schedules (1989, 1999: official print versions of timeschedule; 2011: www.cp.sk, accessed in November 2011); Google Maps database (accessed in November 2011), Autoatlas ĆSSR (1989), Podrobný autoatlas - Slovenská republika (1999). connections with the other regional centres were quite stable, displaying five fully competitive links out of seven in total throughout the surveyed years.

Generally, according to our methodology, we can see a slight improvement of public transport networks in connecting the regional centres of Slovakia after 1989. Out of 28 possible city-to-city interconnections, one can see 11 noncompetitive public transport links in 1989, compared to 10 in 2011. The decreased number of partially competitive links is even more informative: from seven in 1989 down to two in 2011. Although the methods that we used to identify the competitiveness of public transport compared to individual transport might be subject to discussion, we assume that the gradual enhancement of the existing road infrastructure and the modernization of railways in Slovakia are positive for public transport interconnections. This may not be true for regional transport, but that was not the subject of this research. The importance of regional centres, however, forces the public transport operators to do their best to run time-efficient and competitive bus and train links among these major cities.

\section{Conclusions}

There is no doubt that both public and individual means of passenger transport have shown considerable improvement in travel times since the collapse of the socialist regime in Slovakia. Although the motorisation rate of the population grew from 165 vehicles per 1,000 inhabitants in 1990 to 324 in 2011 (Statistical Office of the Slovak Republic) and the population's dependence on passenger cars has accelerated rapidly, public transport still maintains its strong position of a cheap and ecological alternative to individual transport. As shown by this analysis, improvements in the fleet of vehicles and in the network of motorways do not necessarily devalue the importance of public transport.

The results of this research may be expressed in the following four major conclusions:

1. Within the group of eight regional centres, most of the public transport interconnections are covered with both trains and buses. Not surprisingly, in many cases trains are faster that buses, in spite of the fact that the technical conditions of the Slovak railway network are not perfect. However, the cities located along the principal railway corridor Bratislava-Žilina-Košice (being gradually modernized and upgraded to $160 \mathrm{~km} \cdot \mathrm{h}^{-1}$ ) profit from such a position and take advantages of fast and comfortable long-distance train services. Due to the somewhat problematic accessibility of high-capacity 
railway corridors, interconnections with the rest of the regional centres (Nitra, Banská Bystrica and Prešov) are more efficiently covered by bus services.

2. Undoubtedly, travelling by a passenger car is still faster than travelling by bus or train. Both individual and public means of transport have shortened their travel times, but public transport links have generally manifested a more progressive time reduction in the period 1989-2011. We can assume that road network upgrading may have a positive impact on the accessibility of major regional centres by passenger car, but on the other hand, public transport operators still have a significant organizational reserve to cut the traveltimes of buses and trains. Greater liberalization of the railway market and opening the passenger market for several independent long-distance train operators could prime the use of this organizational reserve. At present, there is no long-distance passenger railway operator in Slovakia and the current Slovak government is unlikely to allow any other carriers to penetrate the market and compete with the special-privilege monopoly of the stateowned passenger-train company.

3. Of the eight regional centres, Bratislava has the primary position considering the frequency of public-transport interconnections with the other cities. Regardless of the fact that the frequency of links has grown in all regional centres, Prešov still occupies last place mainly due to its eccentric and peripheral position, being shaded by the nearby larger city of Košice, which can be related to the historical development of the two cities.

4. The synthetic comparison of public transport links and individual transport with a focus on changes after 1989 showed a slightly surprising public transport competitiveness growth. The improvement of public transport services should not be seen as absolute, since public transport schedules are subject to change every year. We can assume that it is mainly the current condition of Slovak railway networks, which inhibits the speed (and capacity) of public transport. Nevertheless, the introduction of new segments of services (especially IC and EC trains in the late 1990s and low cost flights between Bratislava and Košice after 2000), was probably highly stimulating and induced an unprecedented struggle for customers. The decline of freight transport within the Slovak railway network after 1989 allowed more capacity for passenger transport, which may also have contributed to the acceleration of passenger trains in some parts of the railway network. As a result, one can find faster trains and buses offering extrafast services connecting mainly Bratislava and the other regional capitals. In the context of a national transport policy, the complete modernization of main railway corridors in the future might induce highly attractive travel times among the regional capitals, such that no passenger car will be able to compete.

We are fully aware of the fact that the selection of only two basic parameters cannot fully cover the motivation of an individual to use one or another mode of transport. We have omitted principally the parameter of travel cost that may affect the final decision of a traveller in reality. The role of travel expenses and other factors (such as income, car ownership, trip purposes, waiting environment, vehicle characteristics, etc.) may be inspiring for further geographical or interdisciplinary research on public and private transport systems.

\section{Acknowledgement}

This work was supported by the VEGA grant agency under contracts No. 1/0709/11 and No. 1/1143/12.

\section{References:}

Act No. 56/2012 Coll. on Road Transportation

Autoatlas ČSSR (1989) 1:400 000, Praha.

BAXTER, R. S., LENZI, G. (1975): The measurement of relative accessibility. Regional Studies, Vol. 9, No. 1, p. $15-26$.

BEIRĂO, G., SARSFIELD CABRAL, J.A. (2007): Understanding attitudes towards public transport and private car: A qualitative study. Transport Policy, Vol. 14, No. 6, p. 478-489.

BORNDÖRFER, R., GRÖTSCHEL, M., PFETSCH, M. E. (2007): A Column-Generation Approach to Line Planning in Public Transport. Transportation Science, Vol. 41, No. 1, p. 123-132.

BORUTA, T., IVAN, I. (2010): Public Transport in Rural Areas of the Czech Republic - Case Study of the Jeseník Region. Moravian Geographical Reports, Vol. 18, No. 2, pp. 9-22.

BUSSIECK, M. R. (1998): Optimal Lines in Public Rail Transport. Ph.D Thesis, Technische Universität Braunschweig, 133 pp.

CHARLTON, C., VOLWES, T. (2008): Inter-Urban and Regional Transport. In: Knowles, R., Shaw, J., Docherty, I. [ed.]: Transport Geographies - Mobilities, Flows and Spaces, Oxford, Blackwell Publishing, p. 120-136.

COUTO, A., GRAHAM, D. J. (2008): The impact of high-speed technology on railway demand. Transportation, Vol. 35, No. 1,. p. 111-128. 
CUDNY, W. (2011): Model przemian miasta postsocjalistycznego - przykład Łodzi. Studia Miejskie, No. 4, p. $153-159$.

CUDNY, W. (2012): Socio-Economic Changes in Lodz - Results of Twenty Years of System Transformation. Geografický časopis, Vol. 64, No. 1, p. 3-27.

DOLINAYOVÁ, A. (2011): Factors and determinants of modal split in passenger transport. Horizons of railway transport. Scientific papers. Vol. 2, No. 1, p. 33-39.

DŽUPINOVÁ, E., HALÁS, M., HORŇÁK, M., HURBÁNEK, P., KÁČEROVÁ, M., MICHNIAK, D., ONDOŠ, S., ROCHOVSKÁ, A. (2008): Periférnost’ a priestorová polarizácia na území Slovenska. Bratislava, Geografika, 186 pp.

Europe in Figures - Eurostat Yearbook 2011. Luxembourg, Eurostat, 692 pp.

FAITH, P. (2008): Passenger Road Transport Trends in the Slovak Republic. Communications, Vol. 10, No. 3, p. 33-39.

FELLESSON, M., FRIMAN, M. (2008): Perceived satisfaction with public transport services in nine European cities. The Journal of Transportation Research Forum, Vol. 47, No. 3, p. 93-103.

GAŠPARÍK, J., DOLINAYOVÁ, A., MAŠEK, J., HALÁS, M. (2012): Objednávanie výkonov vo verejnom záujme v železničnej doprave v SR. In: Kvizda, M., Tomeš, Z. [eds.]: Konkurence na železnici - budoucnost pro 21. století nebo destrukce sítě? Proceedings of the international seminar Telč 2012, Brno, Masaryk University, p. 15-21.

HINE, J., SCOTT, J. (2000): Seamless, accessible travel: users' views of the public transport journey and interchange. Transport Policy, Vol. 7, p. 217-226.

HORŇÁK, M. (2004): Súčasný stav a perspektívy vývoja dopravnej infraštruktúry Slovenskej republiky. Prace Komisji Geografii Komunikacji Polskiego Towarzystwa Geograficznego, Tom X, p. 231-250.

HORŇÁK, M., DŽUPINOVÁ, E. (2009): Aspects of Marginality in Border Regions of Slovakia - a Case Study. In: Wilk, W. [ed.]: Global Changes: their Regional and Local Aspects, Proceedings of the $6^{\text {th }}$ Polish-Czech-Slovak Geographical Seminar, Warszawa, Uniwersytet Warszawski, p. 123-129.

CHMELÍK, J., KVĚTOŇ, V., MARADA, M. (2010): Evaluation of Competitiveness of Rail Transport on Example of Connection among Regional Capitals in Czechia. Národohospodářský obzor, Vol. 10, No. 1, p. 5-20.

IVAN, I. (2010a): Advantage of carpooling in comparison with individual and public transport. Case study of the Czech Republic. Geographia Technica, Vol. 9, No. 1, p. 36-46.

IVAN, I. (2010b): Simulation of commuting by carpooling in the Czech Republic. In: Horák, J. et al. [eds.]: Advances in Geoinformation Technologies 2010. Ostrava, VŠB - Technical University of Ostrava, p. 151-161.

JAKÓBCZYK-GRYSZKIEWICZ, J. (2011): Łódź u progu XXI wieku. Studia Miejskie, No. 4, p. 131-138.

KEJÍKOVÁ, A. (2008): Výkony vo verejnom záujme v osobnej doprave. Železničná doprava a logistika, Vol. 3, p. 34-36.

KOMORNICKI, T. (2005): Specific Institutional Barriers in Transport Development in the Case of Poland and Other Central European Transition Countries. IATSS Research, Vol. 29, No. 2, p. 50-58.

KOMORNICKI, T. (2008): Changes of car ownership and daily mobility in selected Polish cities. Geografický časopis, Vol. 60, No. 4, p. 339-362.

KRAFT, S. (2012): A transport Classification of Settlement Centres in the Czech Republic Using Cluster Analysis. Moravian Geographical Reports, Vol. 20, No. 3, p. 38-49.

KRAFT, S., VANČURA, M. (2009): Transport Hierarchy of Czech Settlement Centres and its Changes in the Tranformation period: Geographical Analysis. Moravian Geographical Reports, Vol. 17, No. 3, p. 41-52

LIMTANAKOOL, N., DIJST, M., SCHWANEN, T. (2006): The influence of socioeconomic characteristics, land use and travel time considerations on mode choice for medium- and longer-distance trips. Journal of Transport Geography, Vol. 14, p. 327-341.

LOPÉZ-PITA, A., ROBUSTÉ, F. (2005): Impact of High-Speed Lines in Relation to Very High Frequency Air Services. Journal of Public Transportation, Vol. 8, No. 2, p. 17-35.

MARADA, M., KVĚTOŇ, V. (2010): Diferenciace nabídky dopravních př́ležitostí v českých obcích a sociogeografických mikroregionech. Geografie - Sborník ČGS, Vol. 115, No. 1, p. 21-43.

MARADA M., KVĚTOŇ V., VONDRÁČKOVÁ P. (2010): Doprava a geografická organizace společnosti v Česku. Praha, Česká geografická společnost, Praha, 168 pp.

MICHNIAK, D. (2006): Dostupnost okresných a krajských miest na Slovensku. In: Faltan, L., Štrbavá, J. [eds.]: Regionálna diferenciácia Slovenska v podkladových štúdiách. Subtéma 3: Typológia regionálnej diferenciácie v slovenských podmienkach - Dimenzia civilizačno-infraštruktúrna. Bratislava, Sociologický ústav SAV, p. 148-166.

MICHNIAK, D. (2007): Direct International Public Transport Connections of Regional Centres in Slovakia. Europa XXI, Vol. 16, p. 87-100. 
NUTLEY, S. (1998): Rural areas: the accessiblity problem. In: Hoyle, B., Knowles, R., [eds.]: Modern Transport Geography, Chichester, John Wiley and Sons, p. 185-215.

PAUllEY, N., BALCOMBE, R., MACKETT, R., TITHERIDGE, H., PRESTON, J., WARDMAN, M., SHIRES, J., WHITE, P. (2006): The demand for public transport: The effects of fares, quality of service, income and car ownership. Transport Policy Vol. 13, No. 4, p. 295-306.

Podrobný autoatlas - Slovenská republika (1999) 1:100 000, Harmanec.

PŠENKA, T. (2011): Dial'ková vlaková doprava na Slovensku. Železničná doprava a logistika, Vol. 1, p. 57-61

PUCHER, J., BUEHLER, R. (2005): Transport Policies in Central and Eastern Europe. New Brunswick NJ, Rutgers University, 19 pp.

RIETVELD, P., BRUINSMA, F. R., VAN VUUREN, D. J. (2001): Coping with unreliability in public transport chains: a case study for Netherlands. Transportation Research Part A: Policy and Practice, Vol. 35, No. 6, p. 539-559.

SEIDENGLANZ, D. (2005): Přímá železniční spojení z Prahy a Bratislavy (vliv politických a společenských změn). Acta Facultatis Rerum Naturalium Universitatis Comenianae, Geographica, Suppl. No. 3, p. 535-542.

STEG, L. (2003): Can public transport compete with the private car? IATSS Research, Vol. 27, No. 2, p. 27-35.

STEPNIAK, M., ROSIK, M. (2013): Accessibility improvement, territorial cohesion and spillovers: a multidimensional evaluation of two motorway sections in Poland. Journal of Transport Geography, Vol. 31, p. 154-163.

TOLMÁČI, L. (1999): Spádové regióny krajských miest na základe ich asymetrickej váženej dostupnosti. Folia geographica, Vol. 3, p. 305-314.

TOLMÁČI, L. (2002): Dostupnost miest Slovenska. Bratislava: MAPA Slovakia, 66 pp.

TOO, L., EARL, G. (2010): Public transport service quality and sustainable development: A community stakeholder perspective. Sustainable Development, Vol. 18, No. 1, p. 51-61.

VAN DE VELDE, D. (2009): Long distance bus services in Europe: Concession or free market? Discussion paper No. 2009/21, Joint Transport Research Centre, OECD, $21 \mathrm{pp}$.

VAN VUGT, M., MEERTENS, M. R., VAN LANGE, P. A. M. (1995): Car versus public transportation? The role of social value orientations in a real-life social dilemma. Journal of Applied Social Psychology, Vol. 25, No. 3, p. 258-278.

\section{Authors' addresses:}

Mgr. Marcel HORŇÁK, Ph.D., e-mail: hornak@fns.uniba.sk

Mgr. Tomáš PŠENKA, e-mail: tomas.psenka@mindop.sk

Department of Human Geography and Demography

Faculty of Natural Sciences, Comenius University in Bratislava

Mlynská dolina, 84215 Bratislava, Slovakia

RNDr. František KRIŽAN, Ph.D.

Department of Regional Geography, Planning and Environment

Faculty of Natural Sciences, Comenius University in Bratislava

Mlynská dolina, 84215 Bratislava, Slovakia

e-mail:krizan@fns.uniba.sk

Initial submission 8 March 2013, final acceptance 26 September 2013

Please cite this article as:

HORŇÁK, M., PŠENKA, T., KRIŽAN, F. (2013): The competitiveness of the long-distance public transportation system in Slovakia. Moravian Geographical Reports, Vol. 21, No. 4, p. 64-75, DOI: 10.2478/mgr-2013-0021. 